\title{
SISTEM INFORMASI JADWAL SARANA TRANSPORTASI UNTUK KOTA SEMARANG BERBASIS MOBILE APPLICATION
}

\author{
Sesaria Kiki Tamara, Indriyati, Nurdin Bahtiar \\ Jurusan Ilmu Komputer/Informatika, FSM, Universitas Diponegoro \\ sesaria.kt@gmail.com, indri52@yahoo.com,nurdinbahtiar@gmail.com
}

\begin{abstract}
ABSTRAK
Jadwal sarana transportasi merupakan suatu informasi yang banyak dibutuhkan. Karena itu, sudah sepantasnya apabila informasi ini harus mudah didapatkan. Kota Semarang merupakan ibukota dari Provinsi Jawa Tengah serta memiliki sistem transportasi yang besar dan kompleks. Banyak cara yang dapat dilakukan masyarakat untuk mendapatkan informasi tersebut. Salah satunya ialah dengan mencarinya di internet. Namun terkadang hal ini kurang efektif, karena masyarakat harus membuka banyak situs untuk mencari berbagai macam jadwal. Sistem Informasi Jadwal Sarana Transportasi Berbasis Mobile Application untuk Kota Semarang ini dikembangkan sebagai alternatif lain agar masyarakat dapat mengakses bermacam-macam jadwal transportasi dalam satu sistem sehingga menjadi lebih mudah melalui ponsel Android. Pengembangan sistem ini menggunakan JAVA, PHP, dan MySQL. Melalui sistem ini, diharapkan dapat menjadi solusi bagi masyarakat yang ingin mendapatkan jadwal transportasi lebih mudah dan cepat. Selain itu, bagi wisatawan, sistem ini memudahkan wisatawan untuk mencari informasi mengenai sarana transportasi di Kota Semarang.
\end{abstract}

Kata kunci : Jadwal, Transportasi, Sistem Informasi, Mobile Application, Android

\section{PENDAhULUAN}

Smartphone Android merupakan salah satu smartphone yang penggunaannya semakin banyak di kalangan masyarakat saat ini. Android merupakan OS Mobile yang tumbuh di tengah OS lainnya yang berkembang dewasa ini. OS lainnya seperti Windows Mobile, i-Phone OS, Symbian, dan masih banyak lagi yang juga menawarkan kekayaan isi dan keoptimalan berjalan di atas perangkat hardware yang ada.

Pengangkutan atau transportasi mempunyai peranan yang sangat penting dan strategis dalam mendukung segala aspek kehidupan dan penghidupan, baik di bidang ekonomi, sosial-budaya, politik, maupun pertahanan dan keamanan negara. Karena itu, informasi transportasi merupakan salah satu informasi yang sangat dibutuhkan oleh masyarakat.

Kota Semarang merupakan salah satu kota besar karena merupakan ibukota dari Provinsi Jawa Tengah. Sehingga kota ini memiliki sistem transportasi yang besar dan kompleks. Banyak informasi transportasi yang dibutuhkan oleh masyarakat maupun wisatawan di kota ini. Seperti informasi jadwal kereta api, pesawat terbang dan jalur bus. Banyak cara yang dapat dilakukan masyarakat untuk mendapatkan informasi tersebut. Salah satunya ialah dengan mencarinya di internet atau dapat juga membuka situs-situs resmi dari PT KAI, Garuda Indonesia, Air Asia dan lain-lain. Terkadang masyarakat menginginkan berbagai macam informasi jadwal. Hal itu membuat mereka harus mengakses banyak situs, sehingga hal ini tidak efektif.

Dengan adanya sistem ini, masyarakat dapat mengakses bermacam-macam jadwal melalui satu sistem saja sehingga dapat dijadikan sebagai alternatif lain oleh masyarakat.

\section{DASAR TEORI}

\subsection{Sistem Informasi}

Sistem informasi mencakup sejumlah komponen, ada sesuatu yang diproses (data menjadi informasi), dan dimaksudkan untuk mencapai suatu sasaran atau tujuan [4]. Adapun komponen-komponen suatu sistem informasi yaitu perangkat keras (hardware), perangkat lunak (software), prosedur, orang, basis data, jaringan komputer dan komunikasi data. 


\subsection{Mobile Application}

Kata mobile mempunyai arti bergerak atau berpindah. Sehingga diperoleh pengertian bahwa aplikasi bergerak merupakan aplikasi yang dapat dijalankan walaupun pengguna berpindah atau karena pengguna berpindah. Pemrograman aplikasi bergerak tidak banyak berbeda dengan pemrograman konvensional pada PC. Aspek karakteristik dari perangkat bergerak sering mempengaruhi arsitektur dan implementasi dari aplikasi tersebut. Dalam pemrograman aplikasi bergerak berbagai aspek teknis perangkat lebih menonjol karena memiliki banyak keterbatasan dibandingkan komputer konvensional atau PC [1].

\subsection{Sistem Operasi Android}

Android merupakan sistem operasi yang dikembangkan untuk perangkat mobile berbasis Linux [2]. Beberapa komponen fundamental dalam Android antara lain :

\section{a. Activities}

Suatu activity akan menyajikan user interface (UI) kepada pengguna, sehingga pengguna dapat melalukan interaksi. Satu activity biasanya akan dipakai untuk menampilkan aplikasi atau yang bertindak sebagai user interface saat aplikasi diperlihatkan kepada pengguna. [6].

\section{b. Service}

Service pada android tidak memiliki Graphic User Interface (GUI), tetapi service berjalan secara background. Sebagai contoh dalam memainkan musik, media player sedang memutar lagu dari list yang ada, aplikasi ini akan memiliki dua atau lebih activity yang memungkinkan pengguna untuk memilih lagu atau menulis sms sambil musik tetap berjalan. Untuk menjaga musik tetap dijalankan, activity player dapat menjalankan service. Service dijalankan pada thread utama dari proses aplikasi [6].

\section{c. Broadcast Receiver}

Broadcast receiver ini berfungsi menerima dan bereaksi untuk menyampaikan notifikasi. Contoh broadcast ini seperti zona waktu berubah, baterai low, gambar telah selesai diambil oleh kamera atau pengubahan referensi bahasa yang digunakan. Broadcast activity tidak memiliki user interface tetapi memiliki sebuah activity untuk merespon informasi yang mereka terima [6].

\section{d. Content Provider}

Komponen ini membuat kumpulan aplikasi data secara spesifik sehingga dapat digunakan oleh aplikasi lain. Data disimpan dalam file sistem seperti basis data SQLite. Content Provider menyediakan cara untuk mengakses data yang dibutuhkan oleh suatu activity, misalnya ketika pengguna menggunakan aplikasi yang membutuhkan peta (Map), atau aplikasi yang membutuhkan untuk mengakses data kontak dan navigasi [6].

\subsection{Unified Process}

Unified Software Development Process atau biasa disebut sebagai Unified Process merupakan suatu proses pengembangan perangkat lunak. Dalam hal ini perlu dipahami bahwa proses pengembangan perangkat lunak sesungguhnya merupakan aktivitas-aktivitas yang diperlukan untuk menerjemahkan kebutuhan pengguna menjadi sebuah sistem perangkat lunak [3].

Unified Process merupakan proses pengembangan perangkat lunak yang daur hidup (life cycle) nya terdiri atas 4 fase yaitu inception, elaboration, construction, dan transition. Masing-masing fase dapat memiliki satu atau lebih iterasi dan masing-masing iterasi mengeksekusi 5 core workflow yaitu requirement, analysis, design, implementation, dan test.

\subsection{Unified Modelling Language}

Unified Modelling Language (UML) merupakan suatu alat bantu pemodelan visual yang digunakan untuk menspesifikasi, memvisualisasi, mengkonstruksi dan mendokumentasikan suatu sistem khususnya sistem yang dibangun menggunakan pemrograman berorientasi objek. Didalam UML juga menangkap keputusan-keputusan dan pemahaman mengenai sistem yang harus dikonstruksi [5]. 


\section{ANALISIS DAN PERANCANGAN}

\subsection{Deskripsi Sistem}

Sistem Informasi Jadwal Sarana Transportasi (SIJATRA) ini merupakan perangkat lunak mobile yang berfungsi untuk memberikan informasi mengenai jadwal sarana transportasi, seperti jadwal kereta, jadwal pesawat, dan rute bus yang ada di Kota Semarang.

Adapun fitur-fitur yang terdapat pada sistem ini antara lain :

a. Rute Bus

Pada fitur ini pengguna dapat melihat informasi rute bus yang ada di kota Semarang. Terdapat tiga jenis rute bus, yaitu rute trans semarang, rute bus umum dan rute angkot.

b. Jadwal Kereta

Merupakan fitur untuk mencari jadwal kereta yang bersumber pada dua stasiun di Semarang, yaitu stasiun Poncol dan stasiun Tawang. Di sini pengguna dapat mencari nama kereta dan jadwalnya berdasarkan stasiun, dan tujuan keberangkatan.

c. Jadwal Pesawat

Pengguna dapat mengetahui jadwal penerbangan yang ada di bandara Ahmad Yani Semarang. Pencarian jadwal berdasarkan hari dan tujuan keberangkatan.

d. Taxi Dialer

Pada fitur ini, pengguna dapat langsung melakukan panggilan terhadap armada taksi yang diinginkan.

e. Lihat Lokasi

Fitur ini menggunakan Google Maps. Pada fungsi ini dibagi menjadi dua bagian, yaitu fungsi My Location yang melihat titik keberadaan pengguna pada peta serta fungsi Get Direction yang menampilkan jalur di peta untuk tujuan yang diinginkan. Adapun tujuan-tujuan yang ada pada fungsi Get Direction antara lain Terminal Mangkang, Terminal Banyumanik, Terminal Terboyo, Stasiun Poncol, Stasiun Tawang, dan Bandara Ahmad Yani.

\subsection{Model Use Case}

Use case model atau model use case merupakan hasil requirement workflow dari Unified Process. Use case diagram digunakan untuk menunjukkan hubungan antara aktor dengan use case. Gambar 1 menunjukkan use case diagram dari sistem yang akan dibangun.

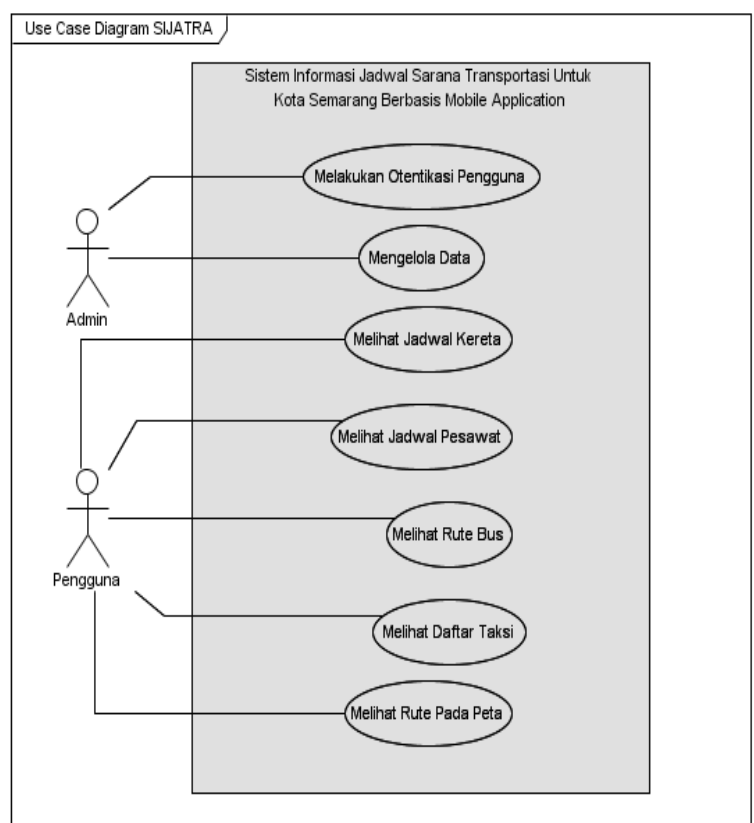

Gambar 1. Use Case Diagram SIJATRA

Penjelasan dari tiap use case dijelaskan dengan use case detail. Tabel 1 menunjukkan salah satu contoh use case detail.

Tabel $1 \quad$ Use Case Detail Melihat Jadwal Kereta

\begin{tabular}{|l|}
\multicolumn{1}{c|}{ Use Case Melihat Jadwal Kereta } \\
\hline ID : UC3 \\
\hline $\begin{array}{l}\text { Actors : } \\
\text { Pengguna }\end{array}$ \\
\hline $\begin{array}{l}\text { Preconditions : } \\
\text { Pengguna membuka SIJATRA pada ponselnya }\end{array}$ \\
\hline $\begin{array}{l}\text { Flow of Events : } \\
\text { 1. Pengguna memilih menu Jadwal Kereta } \\
\text { 2. Pengguna mengisi data pada form pencarian } \\
\text { jadwal kereta }\end{array}$ \\
\hline $\begin{array}{l}\text { Postconditions : } \\
\text { Pencarian jadwal kereta berhasil dilakukan, sistem } \\
\text { menampilkan hasil pencarian }\end{array}$ \\
\hline
\end{tabular}

\subsection{Kebutuhan Non-fungsional}

Non-functional requirements atau kebutuhan non-fungsional menentukan atribut atau kualitas secara keseluruhan dari suatu sistem. Adapun kebutuhan non-functional pada pengembangan SIJATRA ditunjukkan pada Tabel 2. 
Tabel 2. Kebutuhan Non-Fungsional

\begin{tabular}{|l|l|l|}
\hline No & Parameter & Requirement \\
\hline 1. & Availability & $\begin{array}{l}\text { Sistem tersedia dalam 24 } \\
\text { jam sehari, 7 hari } \\
\text { seminggu. }\end{array}$ \\
\hline 2. & Usability & $\begin{array}{l}\text { Tampilan antarmuka } \\
\text { konsisten, pesan kesalahan } \\
\text { yang informatif. }\end{array}$ \\
\hline 3. & Reliability & Tidak pernah gagal. \\
\hline 4. & Performance & $\begin{array}{l}\text { Memiliki respon time } \\
\text { kurang dari 10 detik. }\end{array}$ \\
\hline 5. & Security & $\begin{array}{l}\text { Data hanya diubah oleh } \\
\text { administrator sistem. }\end{array}$ \\
\hline
\end{tabular}

\subsection{Realisasi Use Case Tahap Analisis}

Interaksi antara class analysis dengan fungsional perangkat lunak ditunjukkan dengan realisasi use case. Setiap use case direalisasikan dengan menggunakan analysis class diagram dan communication diagram. Gambar 2 menunjukkan salah satu analysis class diagram dan Gambar 3 menunjukkan salah satu communication diagram.

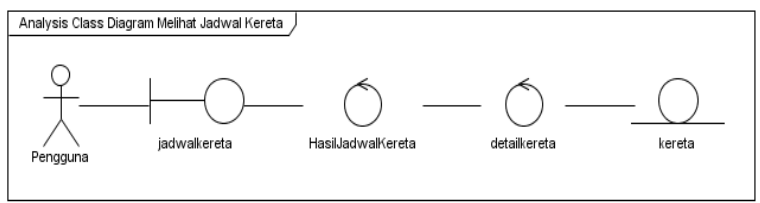

Gambar 2 Analysis Class Diagram Melihat Jadwal Kereta

Analysis class diagram Melihat Jadwal Kereta menunjukkan kelas-kelas yang terkait pada use case Melihat Jadwal Kereta yaitu:

a. Class Boundary: jadwalkereta

b. Class Control : HasilJadwalKereta, detailkereta

c. Class Entity : kereta

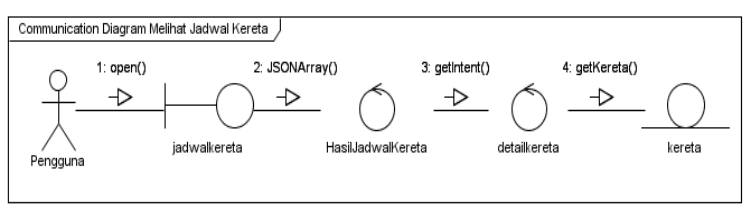

Gambar 3 Communication Diagram Melihat Jadwal Kereta

\subsection{Realisasi Use Case Tahap Perancangan}

Use Case realization tahap perancangan merupakan kolaborasi design class dan objekobjeknya yang merealisasikan use case. Setiap use case direalisasikan dengan menggunakan class diagram.

\subsection{Deployment Diagram}

Pada deployment diagram ini, komponen yang dihasilkan antara lain SIJATRA.apk, Android OS, Apache, Web Browser, DBConnectior, dan MySQL DB. Deployment diagram SIJATRA ditunjukkan pada Gambar 4.

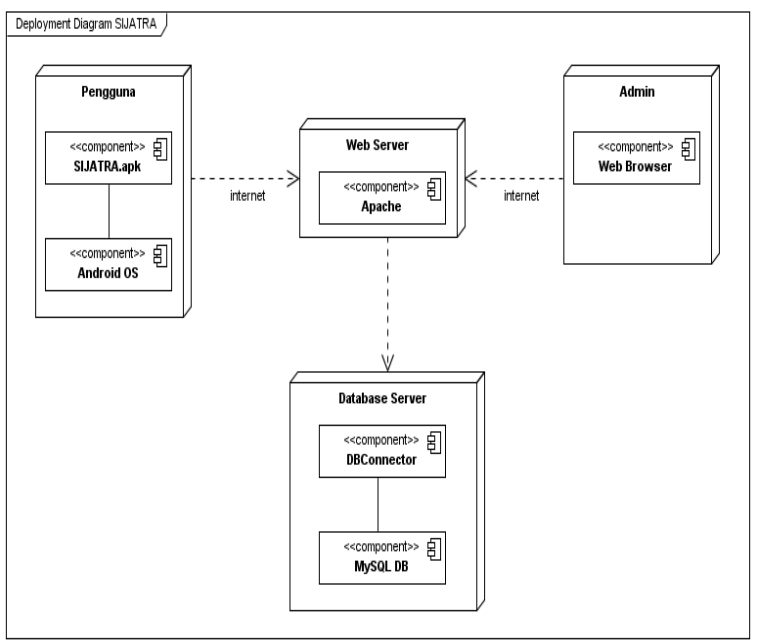

Gambar 4 Deployment Diagram

\subsection{Perancangan Basisdata}

DBMS yang digunakan pada SIJATRA ini adalah basis data relasional. Pemodelan basis data digambarkan dengan class diagram dan ditunjukkan pada Gambar 5. Serta contoh deskripsi perancangan basis data ditunjukkan Tabel 3.

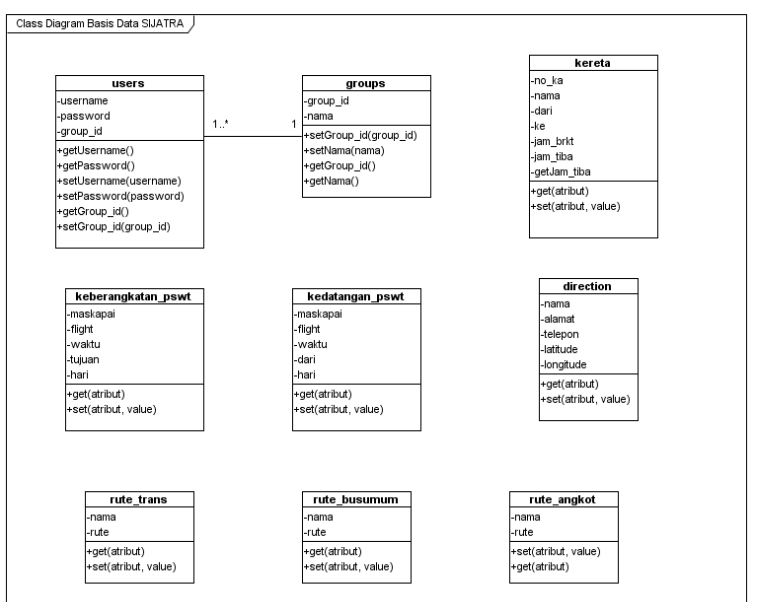

Gambar 5 Class Diagram Perancangan

Basisdata 
Tabel 3 Deskripsi Tabel Jadwal Keberangkatan Pesawat

\begin{tabular}{|c|c|c|c|}
\hline Id Field & Deskripsi & Tipe & $\begin{array}{l}\text { Keteran } \\
\text { gan }\end{array}$ \\
\hline$\frac{\text { departure }}{\text { pid }}$ & Id & $\operatorname{int}(5)$ & $\begin{array}{l}\text { Primary } \\
\text { Key }\end{array}$ \\
\hline tanggal & $\begin{array}{l}\text { Tanggal ketika } \\
\text { memasukkan } \\
\text { data }\end{array}$ & date & \\
\hline maskapai & $\begin{array}{l}\text { Nama maskapai } \\
\text { penerbangan }\end{array}$ & $\begin{array}{l}\text { varchar } \\
(20)\end{array}$ & \\
\hline no_flight & $\begin{array}{l}\text { Nomor } \\
\text { penerbangan } \\
\text { pesawat }\end{array}$ & $\begin{array}{l}\text { varchar } \\
(10)\end{array}$ & \\
\hline waktu & $\begin{array}{l}\text { Waktu } \\
\text { keberangkatan }\end{array}$ & $\begin{array}{l}\text { varchar } \\
\text { (5) }\end{array}$ & \\
\hline tujuan & Tujuan & $\begin{array}{l}\text { varchar } \\
(20)\end{array}$ & \\
\hline hari & Hari & $\begin{array}{l}\text { varchar } \\
\text { (6) }\end{array}$ & \\
\hline harga & Harga tiket & $\begin{array}{l}\text { varchar } \\
(12)\end{array}$ & \\
\hline
\end{tabular}

\section{IMPLEMENTASI DAN PENGUJIAN}

\subsection{Implementasi}

Implementasi ini dilakukan dengan menggunakan perangkat keras dan perangkat lunak. Sistem ini memiliki pengimplementasian yang berbeda bagi masing-masing aktornya. Berikut daftar spesifikasi perangkat keras dan perangkat lunak yang digunakan untuk pengguna yaitu :

a. Smartphone Android dengan versi sistem operasi 2.2 Froyo atau 2.3 Gingerbread

b. Koneksi internet

Sedangkan daftar spesifikasi perangkat keras dan perangkat lunak yang digunakan untuk admin yaitu :
a. CPU : Intel Core i3-2350M Processor 2.30 $\mathrm{GHz}$
b. Memory 2 GB / Hard Disk 320 GB
c. Sistem operasi : Microsoft Windows 7 Home Basic 64bit
d. Eclipse 3.6 Helios beserta emulatornya
e. Android Development Tools (ADT)
f. Android Software Development Kit (SDK)
g. Xampp 1.7.4
h. PhpMyAdmin 3.3.9
i. MySQL 5.0
j. Notepad ++
k. PHP dan JAVA

pada contoh implementasi class dapat dilihat

keberangkatan_pesawat pada kode 1 .

\section{Kode 1 Implementasi Class Entity} keberangkatan_pesawat

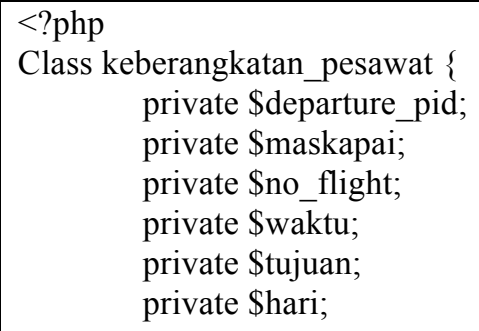

\section{//konstruktor}

public function keberangkatan_pesawat () \{

\}

//selektor

public function getdeparture pid () \{ return \$this->departure_pid; $\}$

public function getmaskapai () \{ return \$this->maskapai;

public function getno_flight ()\{ return \$this->no_flight; $\}$

public function getwaktu () \{ return \$this->waktu; $\}$

public function gettujuan () \{ return \$this->tujuan; $\}$

public function gethari () \{ return \$this->hari; $\}$

$/ /$ mutator

public function setdeparture pid (\$departure_pid) \{ \$this->departure_pid $=$ \$departure_pid; \}

public function setmaskapai (\$maskapai) \{ \$this- $>$ maskapai $=\$$ maskapai $;$ public function setno_flight (\$no_flight) \{ \$this- $>$ no_flight $=\$$ no_flight $;\}$

public function setwaktu (\$waktu) \{ \$this- $>$ waktu $=\$$ waktu; $\}$ public function settujuan (\$tujuan) \{ \$this- $>$ tujuan $=$ \$tujuan; $\}$ public function sethari (\$hari) \{ \$this- $>$ hari $=\$$ hari; $\}$

$?>$ \}

Adapun implementasi antarmuka ditunjukkan pada Gambar 6 hingga Gambar 11 . 


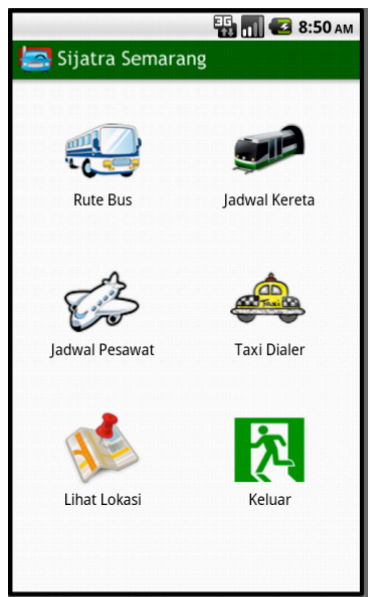

Gambar 6 Tampilan Menu Utama

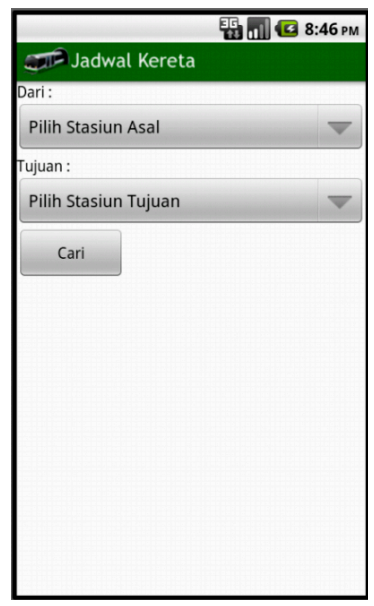

Gambar 7 Tampilan Form Pencarian

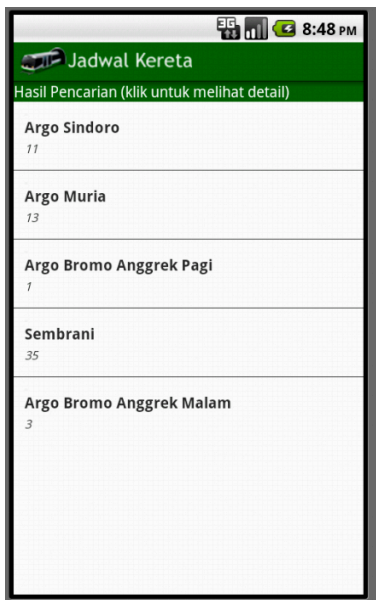

Gambar 8 Tampilan List Hasil Pencarian

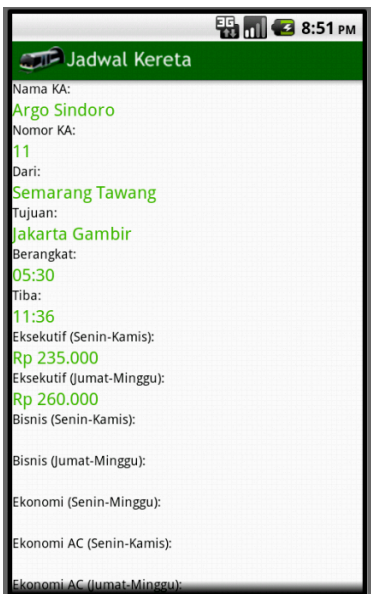

Gambar 9 Tampilan Detail Hasil Pencarian

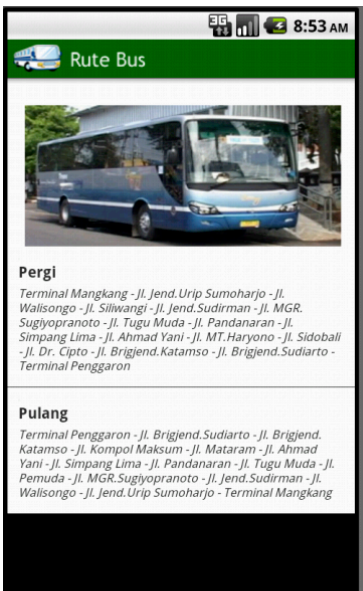

Gambar 10 Tampilan Menu Rute Bus

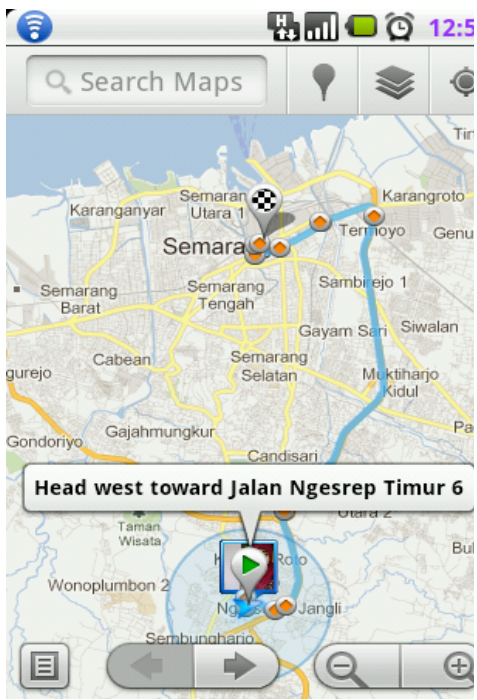

Gambar 11 Tampilan Menu Get Direction 


\subsection{Pengujian}

Pengujian perangkat lunak Sistem Informasi Jadwal Sarana Transportasi untuk Kota Semarang Berbasis Mobile Application (SIJATRA) dilakukan dengan metode black box, yaitu menguji fungsionalitas dari perangkat lunak, tanpa harus mengetahui struktur internal program. Sebuah perangkat lunak yang diuji menggunakan metode black-box dikatakan berhasil jika fitur-fitur yang ada telah memenuhi spesifikasi requirements (use case) yang telah dibuat sebelumnya.

Dari hasil pengujian, dapat diketahui bahwa SIJATRA ini telah memenuhi untuk :
a. Melakukan otentikasi pengguna
b. Mengelola data
c. Melihat jadwal kereta
d. Melihat jadwal pesawat
e. Melihat rute bus
f. Melihat daftar taksi
g. Melihat rute pada peta

\section{KESIMPULAN DAN SARAN}

\subsection{Kesimpulan}

Dihasilkan sebuah sistem informasi jadwal sarana transportasi di Kota Semarang berbasis mobile application bagi pengguna ponsel Android yang dikembangkan dengan menggunakan JAVA, PHP dan MySQL.

Sistem ini memiliki beragam informasi mengenai jadwal transportasi, tidak hanya satu jenis sarana transportasi saja. Hal ini mempermudah masyarakat mencari informasi jadwal dengan transportasi yang berbeda dalam satu aplikasi.

\subsection{Saran}

Untuk pengembangan lebih lanjut, sistem ini dapat dikembangkan dengan menambahkan pengaksesan basis data secara langsung yang terhubung dengan server basis data dari website masing-masing jadwal. Seperti website PT. KAI, Bandara Ahmad Yani, dan lain-lain.

\section{DAFTAR PUSTAKA}

[1] Darytamo, Budi, et all., 2007, "Pemrograman Berorientasi Obyek dengan Java 2 Platform Micro Edition (J2ME)", Bandung: Java Competency Center Institut Teknologi Bandung

[2] Hermawan, Stephanus, 2011, "Mudah Membuat Aplikasi Android", Yogyakarta: Penerbit Andi.

[3] Jacobson, Ivar, et all., 1999, "The Unified Software Development Process", Boston, Addison Wesley Longman inc.

[4] Kadir, Abdul, 2003, "Pengenalan Sistem Informasi", Yogyakarta: Penerbit Andi.

[5] Rumbaugh, James dkk, 1999, "The Unified Modelling Language Reference Manual", Boston: Addison Wesley Longman inc.

[6] Safaat, Nazruddin, 2011, "Pemrograman Aplikasi Mobile Smartphone dan Tablet PC Berbasis Android", Bandung : Penerbit Informatika. 
Sistem Informasi Jadwal Sarana Transportasi untuk Kota Semarang Berbasis Mobile Application 